\section{THE TRAINING AND SUPPLY OF MIDWIVES.}

To the Editors of THE LANCET.

SIRS,--Will you allow me to supplement your kind notice of the meeting held on Nov. 4th by the Association for Promoting the Training and Supply of Midwives, at which the chair was taken by the President, the Archbishop of Canterbury, by saying that the office of the Association is at Dacre House, New Tothill-street, Westminster, and that the secretary, Miss Gill, is there daily for interviews from 10.30 to one o'clock, Saturdays excepted? She will gladly give any information concerning the various branches of our work and the best means of meeting the requirements of the Midwives Act, and we specially want it to be known that we are ready to send speakers to any part of the country to address meetings on the subject.

May I quote, in conclusion, the eloquent words of Mrs. Humphry Ward in her speech at the meeting; as an appeal for the money we need to assist in the training of midwives to supply the dearth that will become more and more evident as those who are incompetent retire from practice under the searchlight of the new regulations: "How many there are still, who, professing to know but knowing nothing, may at any time bring clanger and death upon mother and child! How can we bear to think of a mother being injured in the hour of her trouble-that hour when all the community should be her guardians-when being unable to help herself sbe is ready to trust herself to hands unfit or inexperienced. Every woman of means who rejoices in her own children can belp if she will. She can support this Association, she can give her yearly subscription, she can provide training for one woman, or more if her means are large. She can help women and children who are fighting the battle of life with hands no stronger than her own and with resources so pitifully less."

Subscriptions and donations will be very gratefully received at the office or by the honorary treasurer, Mr. Arthur L. Leon, L.C.C., 20, St. Thomas's Mansions, Westminster Bridge, or by mvself (Mrs. Wallace Bruce, 9, Airlie-gardens, Campden-hill, W.).-I am, Sirs, yours faithfully,

Nov. $28 \mathrm{th}, 1904$. AGNES MABEL BRUCE, Chairman of the Executive Committee.

\section{THE WORLD'S FAIR AT ST LOUIS. \\ (From our Special Sanitary Commissioner.) (Continued from p. 1599.)}

St. Louis, Nov. 15th.

IN the section devoted to the liberal arts the corporations of Liverpool, Manchester, Birmingham, Glasgow, and other towns show what they are doing in respect to drainage, the treatment of sewage, and the housing of the poor. The Indian Public Works Department also has many plans of weirs and irrigation works which have for their main purpose the forwarding of agricultural interests but likewise tend to improve the health of those who live in the better-drained districts. At the other end of the building the exhibits of the German Empire occupy extensive space and there are given most elaborate descriptive illustrations of what has been done. A great number of towns show on the walls maps of their sewers and sectional drawings and give other details. The whole plans with many details of application are given of the waterworks notably of Cologne, Dresden, Hanover, and Munich. Then there is the wonderful sanitary map of tho German Empire which was exhibited in Paris in 1900 . By the side of every town figures give the birth-and death-rate and the amount of litres of water supplied per head of the population, while special signs indicate the nature of the water-supply and the system of the drainage. Then there is a large ca.e which contains drawings and photographs of the German sanatoriums for the treatment of tuberculosis. These are issued by the Board of Health of the German Empire. Most of the buildings are of the pavilion one-storey type but some have three and even four storeys. Broad verandahs and balconies abound, with room for the patients to lie in their beds while under shelter in the open air. The tops of the pine trees are seen above the roofs of these buildings and suggest a balsamic and perfumed atmosphere. Less odoriferous in their character are the sewer farms that abound in Germany, especially on the outskirts of Berlin. These are shown not merely by plans but by large models with little toy trees. The hydropathic resorts exhibit on a large scale, especially Bad Nauheim. We are shown also how patients, when gargling, are separated from each other by glass partitions and have enamelled basins breast high in front of them so as to avoid accidental infection due to splashing. But undoubtedly one of the most instructive and practical of the German exhibits, and one which occupies in the Education Section a large department all to itselff, is that relating to the insurance of workmen. The Government has taken care that this should be as complete as possible. There is even a separate catalogue issued for this exbibit and a veteran German soldier is there all the time to give explanation and technical pamphlets, of which there are a large number translated into English and published especially for the St. Louis exhibition. Here are the statistics in regard to sickness, accidents, invalidism, or old age of the entire working population of Germany. What help the system of compulsory insurance gave in each case can be seen as well as how this most gigantic machinery or organisation has prevented pauperism and has helped to reduce the death-rate. There is probably notning shown in the whole World's Fair that has had a greater and more practical effect.

The building devoted to Education and Social Economy also contains much that relates to the questions bearing on public health. One end of this structure is occupied by the extensive exhibits of the United States Department of Agriculture. It was by an Act of Congress dated July 2nd, 1862, that "colleges of agriculture and mechanic arts" were established. These institutions have received from the nation 11,322,000 acres for educational farming; in money $\$ 31,157,588$ had been given; and more than 50,000 students have been enrolled. One large section of the exhibits of these schools is called the Dairy Laboratory and here much practical information can be obtained on the question of the preservation and sterilisation of milk. T'hus, for instance, it has been demonstrated that to kill the germs of tuberculosis it is not necessary to sterilise milk at a higher temperature than $140^{\circ} \mathrm{F}$. This, it is claimed, is of the greatest importance, for if the temperature is raised to $150^{\circ}$ the galactase is lost and the milk becomes indigestible Also it is not possible to make cheese with milk that has been heated up to $150^{\circ}$. But if the temperature has not exceeded $140^{\circ}$ the cream will rise in the normal way. It is the agricultural school at Madison in Wisconsin that has made the most extensive experiments and researches on this subject. Its twentieth annual report gives details about the experiments. To sterilise the milk a rotary machine is necessary, otherwise the portion of the milk nearest to the source of heat would be overheated and that furthest from it would not be heated enough. Therefore a rotary move. ment to distribute the heat throughout the whole of the milk must be provided. When this was done it was found that from 98.9 to 99.8 per cent. of the bacteria were destroyed. At St. Louis, where sanitary conditions are far from perfect, there are about 3000 cows and the milk which they give is purer and better than the milk imported into the town from the healthier surrounding districts. This is simply due to the greater severity of the sanitary inspection organised within the confines of the town. Here, as in England, the problem presents itself as to how a town can control a milk-supply which for the most part is derived from districts far away from its jurisdiction. In these circumstances the suggestion is made that a regulation might be enforced to the effect that all milk imported from districts not controlled by the town inspectors must be pasteurised before it can be sold. It would then have the advantage of being not only safer but it could be kept for a much longer time. Apart from the question of sterilisation, one of the greatest necessities is to keep milk cool. At New York city the inspectors have the right to destroy all milk offered for sale at a temperature above $50^{\circ} \mathrm{F}$. But the San Francisco authorities have hit on the best device. They simply put on a board the names of the dealers discovered selling milk of an inferior quality. These announcements are copied by the local newspapers and this terror of exposure has been found to be more effective than any number of laws and legal penalties.

Next to the Dairy Laboratory there is a model respiraticn 